\title{
Prostate cancer surface targets for CAR T cell therapy or metastatic prostate cancer in the CAR T cell era: My kingdom for the target!
}

\author{
Sergey V. Kulemzin ${ }^{1}$, Andrey A. Gorchakov ${ }^{1,2}$, Aleksandr V. Taranin ${ }^{1,2}$ \\ ${ }^{1}$ Institute of Molecular and Cellular Biology, Siberian Branch of the Russian Academy of Sciences, Novosibirsk, Russia \\ ${ }^{2}$ Novosibirsk State University, Novosibirsk, Russia
}

Sergey V. Kulemzin, Institute of Molecular and Cellular Biology SB RAS, Lavrentyeva 8/2, Novosibirsk, 630090, Russia
Phone: +7 (383) 3639072

Fax: +7 (383) 3639064

E-mail: skulemzin@mcb.nsc.ru

Citation: Kulemzin SV, Gorchakov AA, Taranin AV. Prostate cancer surface targets for CAR T cell therapy or metastatic prostate cancer in the CAR T cell era: My kingdom for the target! Cell Ther Transplant 2019; 8(4): 19-28.

\section{Summary}

Despite the progress achieved in target, chemo-, and radiotherapy, treatment options for patients with latestage metastatic castration-resistant prostate cancer are presently very limited. Use of dendritic cell-based vaccines exemplified by sipuleucel-T appears is rarely $\mathrm{cu}$ rative and is effective in only a fraction of such patients. Given the success of CAR T cell therapy in the field of $B$ cell malignancies, significant efforts have been made to adapt this powerful technology to the problem of metastatic prostate cancer. Availability of unique prostate cancer surface targets for CAR T cells has thereby become a pressing issue in the field of CAR design. Ideally, such targets should be absent from normal cells or tissues, be present on all prostate cancer cells across all patients, and be indispensable for the survival of cancer cells. In reality, however, none of the prostate cancer-associated surface markers described to date are matching such description. Here, we catalogue the list of tested as well as prospective surface antigens to be used as targets for CAR T cell therapy, and discuss the aspects of their safety and potential efficacy.

\section{Keywords}

Metastatic prostate cancer, immunotherapy, chimeric antigen receptor, CAR T cells.

\section{Introduction}

Treatment of cancer via adoptive transfer of CAR T cells, being proposed over 20 years ago, remained essentially unknown to the broad medical community, largely due to its very limited efficacy observed in clinical trials. CAR T cellbased therapy came into spotlight when complete responses, many of which were long-lasting, had been reported for 50$90 \%$ patients with refractory/relapsed acute lymphoblastic leukemia (r/rALL) and B-cell lymphomas [1-7]. This success stemmed from the relatively easy access of CAR $\mathrm{T}$ cells to cancer cells, as well as from the broad choice of targetable surface markers present on the surface of malignant B cells. In the case of ALL, these markers include pan-B cell antigens such as CD19, CD20, CD22, etc. Accordingly, normal B cells expressing the same surface markers may also be destroyed by CAR T cells $[2,3,5]$. However, this so-called "on-target off-tumor" activity is well tolerated and can be compensated by immunoglobulin replacement therapy [8]. This may not be the case, however, for most other malignancies, since cancer cells often express surface markers that are shared with normal tissues vital to the patient. Thus, the availability of a specific surface marker is central for any successful anti-cancer CAR T cell therapy, including that for prostate cancer (PCa). 


\section{Selecting a CAR target}

An ideal target for CAR-based PCa therapy should display the following features: i) strong and homogeneous expression on metastatic PCa cells and limited or absent expression on non-malignant cells, ii) it should be indispensable for the growth of PCa cells, and/or iii) be enriched on the PCa stem cell population. Comprehensive and unbiased profiling of metastatic PCa-specific surfaceome is therefore warranted as this information would be instrumental for the design of highly selective and potent CARs for the therapy of PCa.

Below we summarize the data on the surface antigens having limited expression outside the prostate and PCa lesions. These targets were used for the preclinical and/or clinical development of CAR T cell-based approaches for PCa or are expected to become CAR T cell targets in the nearest future.

PSCA is a small highly glycosylated GPI-anchored protein with apparent molecular weight of $\sim 24 \mathrm{kDa}$ and predicted molecular weight of only $\sim 10 \mathrm{kDa}$. First described in 1998 , this protein has immediately attracted attention as a potential target for anticancer therapy: it was shown to be highly expressed in primary tumors and metastases of over $80 \%$ PCa patients [9-11], as well as in up to $60 \%$ pancreatic [12, 13] and bladder [14] cancer samples. It should be noted however, that PSCA expression is not restricted to the malignant prostate cells. By profiling human tissues using a PSCA-specific monoclonal antibody 1G8, various levels of PSCA expression were found for normal epithelial (basal, secretory, and neuroendocrine) cells of the prostate, transitional epithelium of the bladder, neuroendocrine cells of the stomach and the colon, as well as for collecting ducts of the kidney [10]. A number of PSCA-specific monoclonal antibodies and humanized variants thereof have been extensively characterized pre-clinically $[15,16]$, however they never proceeded to advanced clinical stages as monotherapy agents. Notably, 1G8-based PSCA-specific CAR T cells were shown to significantly inhibit growth of PSCA-positive non-small cell lung cancer patient-derived xenografts in mice, which provided the rationale for moving towards a clinical trial of CAR $\mathrm{T}$ cells in lung cancer patients (NCT03198052). Furthermore, a "switchable" PSCA-specific GoCAR T cell product (BPX601, Bellicum Pharmaceuticals) is currently in a Phase $1 / 2$ clinical trial for patients with PSCA-positive gastric, pancreatic, and prostate tumors (NCT02744287). Whereas the data for prostate cancer patients are pending, recent analysis of several small cohorts of heavily pre-treated pancreatic patients indicates that BPX-601 infusion combined with a single injection of the small-molecule "switch" has resulted in disease stabilization, which was accompanied by generally moderate and reversible toxicities [17].

Prostate-Specific Membrane Antigen (PSMA) is a type II $100 \mathrm{kDa}$ transmembrane glycoprotein frequently found in both PCa tumors in addition to a limited number of normal human tissues such as prostate epithelium, proximal renal tubules, duodenal, and rectal mucosa $[18,19]$. Interestingly, in the LNCaP cell line widely used for PCa research, PSMA expression is partially modulated by steroid hormones [18]. This recapitulates the in vivo situation, as PSMA expression has been reported to be up-regulated in primary PCa tum- ors and metastases following androgen-deprivation therapy [20]. Nonetheless, different research groups reported the percentage of PSMA-positive prostate tumors to vary from 66 to $100 \%[19,21,22]$, which is likely attributable to the choice of the PSMA-specific antibody. Interestingly, PSMA is known to mark the neovasculature of various non-prostatic cancers $[19,23]$. Several small-molecule inhibitors with high affinity to PSMA and PSMA-specific antibody-drug conjugates have been characterized and are now actively tested for imaging purposes (reviewed in [24]) or as therapeutic agents in Phase 2/3 clinical trials (NCT03042312; NCT02615067; NCT03511664). Excellent safety profile of such PSMA-targeted molecules establishes PSMA as a strong target for CAR $\mathrm{T}$ cells in the context of both metastatic PCa lesions and neovasculature of cancers other than PCa (NCT00664196, NCT01140373, NCT03089203).

ErbB2 (Her2/Neu) is a transmembrane protein known as a prominent marker of breast and gastric carcinomas. Low-level ErbB2 overexpression was found in $~ 20 \%$ of PCa tumors, with stronger expression correlating with rapid cancer cell proliferation and tumor recurrence [25]. Multiple ErbB2 ligands currently approved as therapeutics (such as trastuzumab and pertuzumab) make this protein a convenient target for adoptive cellular immunotherapy of PCa. Although infusion of a ErbB2-specific CAR T cell product has been implicated in a death of a clinical trial participant [26], the reason behind such outcome was likely unrelated to "on-target off-tumor" activity which would be consistent with the broad low-level expression of ErbB2 on normal epithelial cells [27], as this was not observed in a later study where a distinct anti-ErbB2 CAR and significantly lower CAR T cell dose were used [28, 29].

EpCAM (CD326) is frequently found on the surface of carcinomas of various origin, including the prostate, where this antigen was reported to be expressed in up to $87 \%$ of tumors [30]. This protein is also considered to be a cancer stem cell marker [31], which strengthens the idea of its use as a therapeutic target. Yet, EpCAM is also expressed at the basolateral cell membrane of simple, pseudo-stratified, and transitional epithelia, which raises reasonable safety concerns for EpCAM-specific CAR T cell therapy. Presently, EpCAM-specific CAR T cells are in Phase 1/ 2 clinical trials for several solid cancers (NCT02729493, NCT02725125, NCT03563326, NCT02915445) including PCa (NCT03013712).

CD133 (Prominin-1) is one of the several controversial markers of cancer stem cells known to be also expressed by normal stem cells and terminally differentiated epithelial cells [32]. In fact, in the context of PCa, CD133 labels only a subset of cancer stem cells $[33,34]$, which may limit the clinical relevance of this protein as a sole CAR target. It must be noted that a recent clinical trial of CD133-specific CAR T cells for the therapy of patients with hepatocellular, pancreatic, and colorectal carcinomas suggested their overall safety and evidence of limited efficacy [35]. This was consistent with a modest pre-clinical in vitro and in vivo activity of these CAR T cells. Not a single complete response was observed among the 23 treated patients most of whom had very bulky lesions and could not be pre-conditioned. Importantly, CD133+ cells were depleted from the tumor bioptates 
post-treatment and a CD133- tumor escape was observed in one patient. This finding indicates that a two-pronged approach of simultaneously attacking the cancer stem cell population and the tumor cell mass should translate into stronger responses. Therefore, CAR T cells designed to target both CD133 and the surface markers of more differentiated cancer cell types, such as CD133+CEACAM5 or CD133+EGFR, should be more actively explored both pre-clinically and in the clinical setting [36]. So far, no studies of CD133-specific CAR T cells for the therapy of PCa patients have been reported.

Yet another marker of both cancer and hematopoietic stem cells, CD44, is known to be expressed by PCa stem cells [37]. Interestingly, a variant splice form of CD44 known as CD44v6 is not expressed by hematopoietic progenitor cells, and is considered as a favorable target for CAR T cell therapy [38]. CD44v6-retargeted CAR T cells have shown impressive pre-clinical activity in several hematological cancer models $[38,39]$, but none have so far been specifically evaluated in the context of PCa.

PCTA-1 (Galectin 8) was described as the protein expressed on PCa cells back in 1996 [40], however later it received very little attention as a therapeutic target. Likely this was due to the fact that it was and still is unclear how this protein devoid of the signal sequence is trafficked outside the cell and ultimately reaches the cell surface [41-43] and whether its surface expression is truly restricted to cancer cells (reviewed in $[44,45])$. It has recently been demonstrated that patients with metastatic castration-resistant prostate cancer who received Sipuleucel-T produced significantly higher titers of PCTA-1 specific antibodies compared to the control group of patients [46]. This and other observations [47] highlight PCTA- 1 as an emerging therapeutic target in PCa.

STEAP1 has been identified as a membrane protein that is overexpressed in metastatic PCa lesions compared to benign prostatic hyperplasia [48]. It was shown to be also expressed, albeit at much lower levels, by normal prostate and urinary bladder cells, however current expression profiling data are indicative of a much broader normal tissue expression of STEAP1 which includes the brain and the lungs [49]. Whether this inconsistency is associated with the specific choice of antibodies used remains to be explored. Nonetheless, recent clinical trial of MSTP2109A, a conjugate of a humanized anti-STEAP1 antibody and MMAE, has provided evidence of its moderate efficacy in the therapy of patients with metastatic castration-resistant prostate cancer (mCRPC), which was accompanied with a significant percentage of treatment-related serious adverse events [50]. Therefore, considering STEAP-1 as a possible target for CAR T cells may not be regarded as straightforward.

Survivin is broadly known as an intracellular anti-apoptotic protein involved in the control of cell proliferation [51]. It is up-regulated in multiple human cancers including PCa [52]. Intriguingly, this protein has recently been shown to be present on the surface of cancer cells [53], thereby lending itself as a prime candidate for Survivin-specific CARs.

MUC1 is expressed by tumors of a fraction of PCa patients. Across different studies, the percentage of MUC1-positive tumors ranges from $17 \%$ [54] to 58\% [55]. Notably, MUC1 is also expressed by various types of epithelial cells, as well as by hematopoietic cells and activated T cells [56]. This broad expression pattern across multiple normal cell types sets MUC1 as an antigen that appears suboptimal for the target therapy of PCa. Nonetheless, recent efforts from two companies, Minerva Biotechnologies and Poseida Therapeutics, to identify binders that can reliably discriminate between cancer-specific MUC1 species (known as $\mathrm{MUC1}^{\star}$ or MUC1C) and the full-length MUC1 present on normal cells, have translated into the design of CAR T cells [57] showing robust anti-tumor activity in mouse xenotransplant models [58-60], with a Phase I clinical trial of MUC1*-specific CAR T cells announced for breast cancer patients (NCT04020575).

At the same time, Tn Mucl/sTn Mucl species predominantly, although not exclusively expressed on the surface of cancerous, rather than normal tissues serve as attractive alternatives to MUC1 for CAR T cell-based therapy [61, 62], with a recently opened early phase clinical trial of TnMuc1-specific CAR T cells in advanced (non-PCa) solid cancer and multiple myeloma patients (NCT04025216). Except for one report [63], expression of these glycopeptide antigens has been extensively explored using a number of mAbs [64-66] (reviewed in [67]) in cancers other than PCa [61,68]) and warrants further investigation, as the data have been somewhat difficult to reconcile [69].

TAG-72 epitope, established to be a sialyl-Tn O-glycan carbohydrate hapten, has been found in the vast majority of human carcinomas, including PCa. Given its rather restricted expression pattern in normal tissues [70,71] and favorable safety profile of anti-TAG72 mAbs [72,73], first-generation TAG-72-specific CAR T cells have been extensively evaluated both pre-clinically [74] and in two early clinical trials [75] for metastatic colorectal cancer, where they proved to be safe and inefficient largely due to the poor persistence afforded by the CAR design and rapid anti-idiotype elimination. Recent study using local delivery of optimized second-generation TAG-72-CART cells in a xenotransplanted ovarian cancer model [76] provides a strong rationale for testing TAG-72 as a promising target for CAR T cells in epithelial carcinomas including PCa.

Integrin $\mathbf{\alpha v \beta 3}$ is another marker frequently found on PCa cells, as well as on endothelial cells of the tumor vasculature. Expression of this protein is associated with higher risk of metastatic bone lesions [77-79]. Monoclonal av $\beta 3$-specific antibody LM609 and a humanized derivative of LM609 have been characterized in phase I clinical trials which confirmed their safety [80], however no reports of therapeutic activity in the completed phase II clinical trial (NCT00072930) have been posted since 2008, consistent with the complex biology of $\alpha v \beta 3$ in cancer [81]. Intriguingly, a recent study reported on the activity of hLM609-derived av $\beta 3$-specific CAR T cells both in vitro and in vivo, in the setting of xenotransplanted human melanoma [82].

CEACAM5 and CEACAM6 are two related proteins expressed at comparable levels on both $\mathrm{PCa}$ and normal prostate cells [83]. Variable levels of expression of these proteins have also been reported for normal cells of the lung, pancreas, and intestine. Safety of the cell therapy targeting 
CEACAM5 was analyzed in several studies and the results were somewhat conflicting. Use of CEACAM5-specific recTCR-T cells was accompanied with serious colitis in all three patients who received the cell products [84]. This was unlike the situation reported for CEACAM5-specific CAR $\mathrm{T}$ cells based on the MFE23 scFv, where acute respiratory toxicity was observed [85]. Notably, infusion of CEACAM5-specific CAR T cells based on the alternative antigen recognition modules was not accompanied with critical adverse effects in two more clinical studies [86,87]. So far, CEACAM5-specific CAR T cells have not been tested in PCa patients. As for, CEACAM6-specific CAR T cells, the studies have not yet progressed beyond mouse xenotranplant models, and safety of such CAR T cells in humans is presently unknown [88].

TROP-2 (TACSTD2) is expressed on both benign and malignant prostate lesions $[89,90]$, yet it is also detectable on the normal epithelial cells of various origin [91]. No clinical trials of TROP-2-specific CAR T cells have so far been approved, however TROP-2-specific antibody-drug conjugates have been tested in patients and numerous adverse effects have been reported [92]. Hence, the safety of TROP-2-targeted CAR T cell therapy is presently questionable.

Finally, two B7-CD28 family members, B7-H3 (CD276) and B7x (VTCN1/B7-H4) have been reported to be overexpressed in a variety of cancers including PCa [93,94] (reviewed in $[95,96])$, and are currently the focus of pre-clinical CAR T cell evaluation programs using AML [97], lung [98], breast [99], bile duct [100], bone and brain [101-103] cancer cells as the targets. Importantly, the findings of Phase I/IIa clinical trials of B7-H3-specific monoclonal antibody MGA271 (enoblituzumab) support its favorable safety profile [104], although surface expression of B7-H3 has been demonstrated for several normal cell types such as dendritic cells, as well as in vitro activated T-, NK- and B cells [105]. Accordingly, B7-H3-specific CARs did not display appreciable off-tumor activity in pre-clinical tests, but they may still require structural/affinity optimization to robustly discriminate between different expression levels of this antigen on normal and malignant cells upon transition to human trials. Interestingly, delayed lethal off-tumor toxicity has recently been observed for B7x-specific CAR T cells [106].

\section{Conclusion}

None of the abovementioned markers are absolutely specific for PCa or found across PCa lesions in all patients. Furthermore, a fraction of PCa tumors may be expected to be negative for all such markers, and, hence, the feasibility of delivering a targeted CAR therapy would be very low in such cases. Thus, systematic discovery of novel PCa surface markers is highly warranted. Only a handful of studies in this direction have been published to date. For instance, using a combination of proteomic and transcriptomic profiling, Lee and colleagues have identified a number of surface markers enriched in PCa subtypes [107]. Whereas the identification of known PCa markers such as CEACAM5, PSMA, STEAP1, MUC1, and TROP-2 clearly validates this approach, the rest of the high-ranking proteins reported appear to be strongly and broadly expressed in essential tissues, which makes unlikely their potential use as CAR targets.
Analysis of antibodies present in the sera of convalescent cancer patients following immunotherapy who have developed an anticancer immune response may represent an interesting resource of antigen-recognition modules in CAR design. In line with this idea, GuhaThakurta and colleagues have profiled the specificity of antibodies from $25 \mathrm{mCRPC}$ patients who received a dendritic cell-based vaccine sipuleucel-T [46]. Moderate, yet significant increase in antibody titers to PCTA-1 and Galectin-3 among others was observed. The former protein has already been known as a PCa marker, whereas the latter is predominantly secreted, and is a poor candidate for CAR targeting. Nonetheless, in our opinion this approach appears highly promising. In the context of other types of cancer, antibody profiling has identified a number of putative cancer markers including Galectin-1 [108], MYPT1, PSMC5, etc [109]. Importantly, despite the fact that the above proteins lack protein domains that would anchor them at the cell surface, this approach may still be fruitful once substantially more patient samples are analyzed. Of special interest is the recent advance in the technology of single-cell profiling of repertoires of B- and T- cell receptors [110], which may help identify target-receptor pairs, once combined with the proteomics data. Using the above approaches, analysis of samples from more PCa patients may be required to capture novel or subtype-specific PCa markers, or to confidently conclude that no such targets beyond the described ones exist, and that combinations of the known targets should be exploited for CAR design.

\section{Acknowledgements}

This work was supported by the Russian Ministry of Education and Science (Agreement \# 075-15-2019-1246, unique project identifier RFMEFI60417X0169).

The authors report no conflicts of interests.

\section{References}

1. Brentjens RJ, Davila ML, Riviere I, Park J, Wang X, Cowell LG, Bartido S, Stefanski J, Taylor C, Olszewska M, Borquez-Ojeda O, Qu J, Wasielewska T, He Q, Bernal Y, Rijo IV, Hedvat C, Kobos R, Curran K, Steinherz P, Jurcic J, Rosenblat T, Maslak P, Frattini M, Sadelain M. CD19-targeted $\mathrm{T}$ cells rapidly induce molecular remissions in adults with chemotherapy-refractory acute lymphoblastic leukemia. Sci Transl Med. 2013; 5 (177): 177ra138.

2. Lee DW, Kochenderfer JN, Stetler-Stevenson M, Cui YK, Delbrook C, Feldman SA, Fry TJ, Orentas R, Sabatino M, Shah NN, Steinberg SM, Stroncek D, Tschernia N, Yuan C, Zhang H, Zhang L, Rosenberg SA, Wayne AS, Mackall CL. $\mathrm{T}$ cells expressing CD19 chimeric antigen receptors for acute lymphoblastic leukaemia in children and young adults: a phase 1 dose-escalation trial. Lancet. 2015; 385 (9967): 517528.

3. Maude SL, Frey N, Shaw PA, Aplenc R, Barrett DM, Bunin NJ, Chew A, Gonzalez VE, Zheng Z, Lacey SF, Mahnke YD, Melenhorst JJ, Rheingold SR, Shen A, Teachey DT, Levine $\mathrm{BL}$, June $\mathrm{CH}$, Porter DL, Grupp SA. Chimeric antigen receptor T cells for sustained remissions in leukemia. N Engl J Med. 2014; 371(16): 1507-1517. 
4. Turtle CJ, Hanafi LA, Berger C, Gooley TA, Cherian S, Hudecek M, Sommermeyer D, Melville K, Pender B, Budiarto TM, Robinson E, Steevens NN, Chaney C, Soma L, Chen X, Yeung C, Wood B, Li D, Cao J, Heimfeld S, Jensen MC, Riddell SR, Maloney DG. CD19 CAR-T cells of defined CD4+:CD8+ composition in adult B cell ALL patients. J Clin Invest. 2016; 126 (6): 2123-2138.

5. Fry TJ, Shah NN, Orentas RJ, Stetler-Stevenson M, Yuan CM, Ramakrishna S, Wolters P, Martin S, Delbrook C, Yates B, Shalabi H, Fountaine TJ, Shern JF, Majzner RG, Stroncek DF, Sabatino M, Feng Y, Dimitrov DS, Zhang L, Nguyen S, Qin H, Dropulic B, Lee DW, Mackall CL. CD22-targeted CAR T cells induce remission in B-ALL that is naive or resistant to CD19-targeted CAR immunotherapy. Nat Med. 2018; 24(1): 20-28.

6. Maude SL, Laetsch TW, Buechner J, Rives S, Boyer M, Bittencourt H, Bader P, Verneris MR, Stefanski HE, Myers GD, Qayed M, De Moerloose B, Hiramatsu H, Schlis K, Davis KL, Martin PL, Nemecek ER, Yanik GA, Peters C, Baruchel A, Boissel N, Mechinaud F, Balduzzi A, Krueger J, June CH, Levine BL, Wood P, Taran T, Leung M, Mueller KT, Zhang Y, Sen K, Lebwohl D, Pulsipher MA, Grupp SA. Tisagenlecleucel in children and young adults with B-cell lymphoblastic leukemia. N Engl J Med. 2018; 378 (5): 439-448.

7. Park JH, Riviere I, Gonen M, Wang X, Senechal B, Curran KJ, Sauter C, Wang Y, Santomasso B, Mead E, Roshal M, Maslak P, Davila M, Brentjens RJ, Sadelain M. Long-term follow-up of CD19 CAR therapy in acute lymphoblastic leukemia. New Engl J Med. 2018; 378 (5): 449-459.

8. Doan A, Pulsipher MA. Hypogammaglobulinemia due to CAR T-cell therapy. Pediatr Blood Cancer. 2018;65(4). doi: $10.1002 /$ pbc.26914.

9. Reiter RE, Gu Z, Watabe T, Thomas G, Szigeti K, Davis E, Wahl M, Nisitani S, Yamashiro J, Le Beau MM, Loda M, Witte ON. Prostate stem cell antigen: a cell surface marker overexpressed in prostate cancer. Proc Natl Acad Sci USA. 1998; 95 (4): 1735-1740.

10. Gu Z, Thomas G, Yamashiro J, Shintaku IP, Dorey F, Raitano A, Witte ON, Said JW, Loda M, Reiter RE. Prostate stem cell antigen (PSCA) expression increases with high Gleason score, advanced stage and bone metastasis in prostate cancer. Oncogene. 2000; 19(10): 1288-1296.

11. Ross S, Spencer SD, Holcomb I, Tan C, Hongo J, Devaux B, Rangell L, Keller GA, Schow P, Steeves RM, Lutz RJ, Frantz G, Hillan K, Peale F, Tobin P, Eberhard D, Rubin MA, Lasky LA, Koeppen H. Prostate stem cell antigen as therapy target: tissue expression and in vivo efficacy of an immunoconjugate. Cancer Res. 2002; 62(9): 2546-2553.

12. Katari UL, Keirnan JM, Worth AC, Hodges SE, Leen AM, Fisher WE, Vera JF. Engineered T cells for pancreatic cancer treatment. HPB (Oxford). 2011, 13 (9): 643-650.

13. Argani P, Rosty C, Reiter RE, Wilentz RE, Murugesan SR, Leach SD, Ryu B, Skinner HG, Goggins M, Jaffee EM, Yeo CJ, Cameron JL, Kern SE, Hruban RH. Discovery of new markers of cancer through serial analysis of gene expression: prostate stem cell antigen is overexpressed in pancreatic adenocarcinoma. Cancer Res. 2001;61(11):4320-4324.
14. Amara N, Palapattu GS, Schrage M, Gu Z, Thomas GV, Dorey F, Said J, Reiter RE. Prostate stem cell antigen is overexpressed in human transitional cell carcinoma. Cancer Res. 2001; 61(12): 4660-4665.

15. Saffran DC, Raitano AB, Hubert RS, Witte ON, Reiter RE, Jakobovits A. Anti-PSCA mAbs inhibit tumor growth and metastasis formation and prolong the survival of mice bearing human prostate cancer xenografts. Proc Nat Acad Sci USA. 2001; 98 (5): 2658-2663.

16. Olafsen T, Gu Z, Sherman MA, Leyton JV, Witkosky ME, Shively JE, Raubitschek AA, Morrison SL, Wu AM, Reiter RE. Targeting, imaging, and therapy using a humanized antiprostate stem cell antigen (PSCA) antibody. J Immunother. 2007; 30(4): 396-405.

17. Becerra CR, Manji GA, Kim DW, Gardner O, Malankar A, Shaw J, Blass D, Yi X, Foster AE, Woodard P. Ligand-inducible, prostate stem cell antigen (PSCA)-directed GoCAR-T cells in advanced solid tumors: Preliminary results with cyclophosphamide (Cy) \pm fludarabine (Flu) lymphodepletion (LD). J Clin Oncol. 2019; 37 (15_suppl): 2536-2536.

18. Israeli RS, Powell CT, Corr JG, Fair WR, Heston WD. Expression of the prostate-specific membrane antigen. Cancer Res. 1994; 54 (7):1807-1811.

19. Silver DA, Pellicer I, Fair WR, Heston WD, Cordon-Cardo C. Prostate-specific membrane antigen expression in normal and malignant human tissues. Clin Cancer Res. 1997; 3 (1): 81-85.

20. Wright GL Jr, Grob BM, Haley C, Grossman K, Newhall K, Petrylak D, Troyer J, Konchuba A, Schellhammer PF, Moriarty R. Upregulation of prostate-specific membrane antigen after androgen-deprivation therapy. Urology. 1996; 48(2): 326-334.

21. Bostwick DG, Pacelli A, Blute M, Roche P, Murphy GP. Prostate-specific membrane antigen expression in prostatic intraepithelial neoplasia and adenocarcinoma: a study of 184 cases. Cancer. 1998; 82(11): 2256-2261.

22. Mhawech-Fauceglia P, Zhang S, Terracciano L, Sauter G, Chadhuri A, Herrmann FR, Penetrante R. Prostate-specific membrane antigen (PSMA) protein expression in normal and neoplastic tissues and its sensitivity and specificity in prostate adenocarcinoma: an immunohistochemical study using mutiple tumour tissue microarray technique. Histopathology. 2007; 50 (4): 472-483.

23. Chang SS, Reuter VE, Heston WD, Bander NH, Grauer LS, Gaudin PB. Five different anti-prostate-specific membrane antigen (PSMA) antibodies confirm PSMA expression in tumor-associated neovasculature. Cancer Res. 1999; 59 (13): 3192-3198.

24. Afshar-Oromieh A, Babich JW, Kratochwil C, Giesel FL, Eisenhut M, Kopka K, Haberkorn U. The rise of PSMA ligands for diagnosis and therapy of prostate cancer. J Nucl Med. 2016; 57 (Suppl 3): 170720.

25. Minner S, Jessen B, Stiedenroth L, Burandt E, Kollermann J, Mirlacher M, Erbersdobler A, Eichelberg C, Fisch M, Brummendorf TH, Bokemeyer C, Simon R, Steuber T, Graefen M, Huland H, Sauter G, Schlomm T. Low 
level HER2 overexpression is associated with rapid tumor cell proliferation and poor prognosis in prostate cancer. Clin Cancer Res. 2010; 16(5): 1553-1560.

26. Morgan RA, Yang JC, Kitano M, Dudley ME, Laurencot CM, Rosenberg SA. Case report of a serious adverse event following the administration of $\mathrm{T}$ cells transduced with a chimeric antigen receptor recognizing ERBB2. Mol Ther. 2010; 18(4): 843-851.

27. Press MF, Cordon-Cardo C, Slamon DJ. Expression of the HER-2/neu proto-oncogene in normal human adult and fetal tissues. Oncogene. 1990;5 (7): 953-962.

28. Ahmed N, Brawley VS, Hegde M, Robertson C, Ghazi A, Gerken C, Liu E, Dakhova O, Ashoori A, Corder A, Gray T, Wu MF, Liu H, Hicks J, Rainusso N, Dotti G, Mei Z, Grilley B, Gee A, Rooney CM, Brenner MK, Heslop HE, Wels WS, Wang LL, Anderson P, Gottschalk S. Human epidermal growth factor receptor 2 (HER2) -specific chimeric antigen receptor-modified $\mathrm{T}$ cells for the immunotherapy of HER2-positive sarcoma. J Clin Oncol. 2015; 33(15): 16881696.

29. Navai SA, Derenzo C, Joseph S, Sanber K, Byrd T, Zhang H, Mata M, Gerken C, Shree A, Mathew PR, Dakhova O, Salsman V, Hicks J, Yi Z, Wu M-F, Wang T, Grilley B, Rooney C, Brenner M, Heslop H, Gee A, Gottschalk S, Ahmed N, Hegde M. Abstract LB-147: Administration of HER2-CAR T cells after lymphodepletion safely improves $\mathrm{T}$ cell expansion and induces clinical responses in patients with advanced sarcomas. Cancer Res. 2019; 79 (13 Supplement): LB-147LB-147.

30. Went P, Vasei M, Bubendorf L, Terracciano L, Tornillo L, Riede U, Kononen J, Simon R, Sauter G, Baeuerle PA. Frequent high-level expression of the immunotherapeutic target Ep-CAM in colon, stomach, prostate and lung cancers. Br J Cancer. 2006; 94(1): 128-135.

31. Visvader JE, Lindeman GJ. Cancer stem cells in solid tumours: accumulating evidence and unresolved questions. Nat Rev Cancer. 2008; 8(10): 755-768.

32. Glumac PM, LeBeau AM. The role of CD133 in cancer: a concise review. Clin Transl Med. 2018; 7(1): 018-0198.

33. Pellacani D, Oldridge EE, Collins AT, Maitland NJ. Prominin-1 (CD133) expression in the prostate and prostate cancer: A marker for quiescent stem cells. Adv Exp Med Biol. 2013; 777: 167-184.

34. Van der Griend DJ, Karthaus WL, Dalrymple S, Meeker A, DeMarzo AM, Isaacs JT. The role of CD133 in normal human prostate stem cells and malignant cancer-initiating cells. Cancer Res. 2008; 68 (23): 9703-9711.

35. Wang Y, Chen M, Wu Z, Tong C, Dai H, Guo Y, Liu Y, Huang J, Lv H, Luo C, Feng KC, Yang QM, Li XL, Han W. CD133-directed CAR T cells for advanced metastasis malignancies: A phase I trial. Oncoimmunology. 2018; 7(7): e1440169.

36. Feng KC, Guo YL, Liu Y, Dai HR, Wang Y, Lv HY, Huang JH, Yang QM, Han WD. Cocktail treatment with EGFR-specific and CD133-specific chimeric antigen receptor-modi- fied $\mathrm{T}$ cells in a patient with advanced cholangiocarcinoma. J Hematol Oncol. 2017; 10 (1): 4.

37. Maitland NJ, Collins AT. Prostate cancer stem cells: a new target for therapy. J Clin Oncol. 2008, 26(17): 2862-2870.

38. Casucci M, Nicolis di Robilant B, Falcone L, Camisa B, Norelli M, Genovese P, Gentner B, Gullotta F, Ponzoni M, Bernardi M, Marcatti M, Saudemont A, Bordignon C, Savoldo B, Ciceri F, Naldini L, Dotti G, Bonini C, Bondanza A. CD44v6-targeted T cells mediate potent antitumor effects against acute myeloid leukemia and multiple myeloma. Blood. 2013; 122 (20): 3461-3472.

39. Casucci M, Falcone L, Camisa B, Norelli M, Porcellini S, Stornaiuolo A, Ciceri F, Traversari C, Bordignon C, Bonini C, Bondanza A. Extracellular NGFR spacers allow efficient tracking and enrichment of fully functional CAR-T cells co-expressing a suicide gene. Front Immunol. 2018; 9 (507).

40. Su ZZ, Lin J, Shen R, Fisher PE, Goldstein NI, Fisher PB. Surface-epitope masking and expression cloning identifies the human prostate carcinoma tumor antigen gene PCTA$1 \mathrm{a}$ member of the galectin gene family. Proc Nat Acad Sci USA. 1996; 93(14): 7252-7257.

41. Delacour D, Koch A, Jacob R. The role of galectins in protein trafficking. Traffic. 2009; 10(10): 1405-1413.

42. Hughes RC. Secretion of the galectin family of mammalian carbohydrate-binding proteins. Biochim Biophys Acta. 1999; 6 (1): 172-185.

43. Satelli A, Rao PS, Gupta PK, Lockman PR, Srivenugopal KS, Rao US. Varied expression and localization of multiple galectins in different cancer cell lines. Oncol Rep. 2008; 19(3): 587-594.

44. Bidon N, Brichory F, Bourguet P, Le Pennec JP, Dazord L. Galectin-8: a complex sub-family of galectins (Review). Int J Mol Med. 2001; 8(3): 245-250.

45. Bidon-Wagner N, Le Pennec JP. Human galectin-8 isoforms and cancer. Glycoconj J. 2002; 19(7-9): 557-563.

46. GuhaThakurta D, Sheikh NA, Fan LQ, Kandadi H, Meagher TC, Hall SJ, Kantoff PW, Higano CS, Small EJ, Gardner TA, Bailey K, Vu T, DeVries T, Whitmore JB, Frohlich MW, Trager JB, Drake CG. Humoral immune response against nontargeted tumor antigens after treatment with Sipuleucel-T and its association with improved clinical outcome. Clin Cancer Res. 2015; 21(16): 3619-3630.

47. Gentilini LD, Jaworski FM, Tiraboschi C, Perez IG, Kotler ML, Chauchereau A, Laderach DJ, Compagno D. Stable and high expression of Galectin-8 tightly controls metastatic progression of prostate cancer. Oncotarget. 2017; 8(27): 44654-44668.

48. Hubert RS, Vivanco I, Chen E, Rastegar S, Leong K, Mitchell SC, Madraswala R, Zhou Y, Kuo J, Raitano AB, Jakobovits A, Saffran DC, Afar DE. STEAP: a prostate-specific cell-surface antigen highly expressed in human prostate tumors. Proc Nat Acad Sci USA. 1999; 96 (25): 14523-14528.

49. Uhlen M, Fagerberg L, Hallstrom BM, Lindskog C, Oksvold P, Mardinoglu A, Sivertsson A, Kampf C, Sjostedt E, Asplund A, Olsson I, Edlund K, Lundberg E, Navani S, 
Szigyarto CA, Odeberg J, Djureinovic D, Takanen JO, Hober S, Alm T, Edqvist PH, Berling H, Tegel H, Mulder J, Rockberg J, Nilsson P, Schwenk JM, Hamsten M, von Feilitzen K, Forsberg M, Persson L, Johansson F, Zwahlen M, von Heijne G, Nielsen J, Ponten F. Proteomics. Tissue-based map of the human proteome. Science. 2015, 347 (6220): 1260419. doi: 10.1126/science. 1260419.

50. Danila DC, Szmulewitz RZ, Baron AD, Higano CS, Scher HI, Morris MJ, Gilbert H, Brunstein F, Lemahieu V, Kabbarah O, Fine BM, Maslyar DJ, Vaishampayan UN. A phase I study of DSTP3086S, an antibody-drug conjugate (ADC) targeting STEAP-1, in patients (pts) with metastatic castration-resistant prostate cancer (CRPC). J Clin Oncol 2014; 32 (15_suppl): 5024-5024.

51. Wheatley SP, Altieri DC. Survivin at a glance. J Cell Sci. 2019; 132(7): jcs223826.

52. Eslami M, Khamechian T, Mazoochi T, Ehteram H, Sehat M, Alizargar J. Evaluation of survivin expression in prostate specimens of patients with prostate adenocarcinoma and benign prostate hyperplasia underwent transurethral resection of the prostate or prostatectomy. Springerplus. 2016;5:621. doi: 10.1186/s40064-016-2283-5.

53. Fenstermaker RA, Figel SA, Qiu J, Barone TA, Dharma SS, Winograd EK, Galbo PM, Wiltsie LM, Ciesielski MJ. Survivin monoclonal antibodies detect survivin cell surface expression and inhibit tumor growth in vivo. Clin Cancer Res. 2018; 24 (11): 2642-2652.

54. O'Connor JC, Julian J, Lim SD, Carson DD. MUC1 expression in human prostate cancer cell lines and primary tumors. Prostate Cancer Prostatic Dis. 2005; 8 (1): 36-44.

55. Cozzi PJ, Wang J, Delprado W, Perkins AC, Allen BJ, Russell PJ, Li Y. MUC1, MUC2, MUC4, MUC5AC and MUC6 expression in the progression of prostate cancer. Clin. Exp. Metastasis. 2005; 22 (7): 565-573.

56. Brayman M, Thathiah A, Carson DD. MUC1: a multifunctional cell surface component of reproductive tissue epithelia. Reprod Biol Endocrinol. 2004; 2:4.

57. Bamdad CC, Stewart AK, Smagghe BJ, Deary LT, Kohler VL, Dietz JL. Abstract 3330: MUC1 ${ }^{\star}$ targeting CAR T. Cancer Res. 2017; 77 (13 Supplement): 3330-3330.

58. Bamdad C, Stewart AK, Smagghe BJ, Glennie ND, Huang P, Moe S, Swanson T, Jeon T. First-in-human CAR T for solid tumors targets the MUC1 transmembrane cleavage product. Cytotherapy. 2019; 21(5): S9.

59. Bamdad C, Stewart AK, Smagghe BJ, Huang P, Glennie ND, Deary LT. Novel CAR T that targets MUC1* not fulllength MUC1 for treatment of solid tumor cancers. Cytotherapy. 2018; 20 (5): S7.

60. Bamdad CC, Stewart AK, Smagghe BJ, Huang P, Deary LT, Glennie ND. Anti-MUC1* CAR T for solid tumors. Cancer Res. 2018; 78 (13 Supplement): Abstract 2544.

61. Posey AD, Jr., Schwab RD, Boesteanu AC, Steentoft C, Mandel U, Engels B, Stone JD, Madsen TD, Schreiber K, Haines KM, Cogdill AP, Chen TJ, Song D, Scholler J, Kranz DM, Feldman MD, Young R, Keith B, Schreiber H,
Clausen H, Johnson LA, June CH. Engineered CAR T cells targeting the cancer-associated Tn-glycoform of the membrane mucin MUC1 control adenocarcinoma. Immunity. 2016; 44(6):1444-1454.

62. Zhou R, Yazdanifar M, Roy LD, Whilding LM, Gavrill A, Maher J, Mukherjee P. CAR T cells targeting the tumor MUC1 glycoprotein reduce triple-negative breast cancer growth. Front. Immunol. 2019; 10 (1149).

63. Arai T, Fujita K, Fujime M, Irimura T. Expression of sialylated MUC1 in prostate cancer: relationship to clinical stage and prognosis. Int J Urol. 2005; 12 (7): 654-661.

64. Tarp MA, Sorensen AL, Mandel U, Paulsen H, Burchell J, Taylor-Papadimitriou J, Clausen H. Identification of a novel cancer-specific immunodominant glycopeptide epitope in the MUC1 tandem repeat. Glycobiology. 2007; 17(2): 197209.

65. Blixt O, Lavrova OI, Mazurov DV, Clo E, Kracun SK, Bovin NV, Filatov AV. Analysis of Tn antigenicity with a panel of new IgM and IgG1 monoclonal antibodies raised against leukemic cells. Glycobiology. 2012; 22(4): 529-542.

66. Song W, Delyria ES, Chen J, Huang W, Lee JS, Mittendorf EA, Ibrahim N, Radvanyi LG, Li Y, Lu H, Xu H, Shi Y, Wang LX, Ross JA, Rodrigues SP, Almeida IC, Yang X, Qu J, Schocker NS, Michael K, Zhou D. MUC1 glycopeptide epitopes predicted by computational glycomics. Int J Oncol. 2012; 41(6): 1977-1984.

67. Zhou D, Xu L, Huang W, Tonn T. Epitopes of MUC1 tandem repeats in cancer as revealed by antibody crystallography: toward glycopeptide signature-guided therapy. Molecules. 2018; 23 (6): E1326.

68. Lavrsen K, Madsen CB, Rasch MG, Woetmann A, Odum N, Mandel U, Clausen H, Pedersen AE, Wandall HH. Aberrantly glycosylated MUC1 is expressed on the surface of breast cancer cells and a target for antibody-dependent cell-mediated cytotoxicity. Glycoconj J. 2013; 30 (3): 227236.

69. Li Q, Anver MR, Butcher DO, Gildersleeve JC. Resolving conflicting data on expression of the Tn antigen and implications for clinical trials with cancer vaccines. Mol Cancer Ther. 2009; 8 (4): 971-979.

70. Thor A, Ohuchi N, Szpak CA, Johnston WW, Schlom J. Distribution of oncofetal antigen tumor-associated glycoprotein-72 defined by monoclonal antibody B72.3. Cancer Res. 1986; 46 (6): 3118-3124.

71. Xu M, Real FX, Welt S, Schüssler MH, Oettgen HF, Old LJ. Expression of tag-72 in normal colon, transitional mucosa, and colon cancer. Int J Cancer. 1989; 44 (6): 985-989.

72. Meredith RF, Bueschen AJ, Khazaeli MB, Plott WE, Grizzle WE, Wheeler RH, Schlom J, Russell CD, Liu T, LoBuglio AF. Treatment of metastatic prostate carcinoma with radiolabeled antibody CC49. J Nucl Med. 1994; 35(6): 1017-1022.

73. Murray JL, Macey DJ, Kasi LP, Rieger P, Cunningham J, Bhadkamkar V, Zhang HZ, Schlom J, Rosenblum MG, Podoloff DA. Phase II radioimmunotherapy trial with 131ICC49 in colorectal cancer. Cancer. 1994; 73 (3 Suppl): 10571066. 
74. McGuinness RP, Ge Y, Patel SD, Kashmiri SV, Lee HS, Hand PH, Schlom J, Finer MH, McArthur JG. Anti-tumor activity of human $\mathrm{T}$ cells expressing the CC49-zeta chimeric immune receptor. Hum Gene Ther. 1999; 10 (2): 165-173.

75. Hege KM, Bergsland EK, Fisher GA, Nemunaitis JJ, Warren RS, McArthur JG, Lin AA, Schlom J, June CH, Sherwin SA. Safety, tumor trafficking and immunogenicity of chimeric antigen receptor (CAR)-T cells specific for TAG-72 in colorectal cancer. J Immunother. Cancer. 2017; 5(22): 0170222 .

76. Murad JP, Kozlowska AK, Lee HJ, Ramamurthy M, Chang W-C, Yazaki P, Colcher D, Shively J, Cristea M, Forman SJ, Priceman SJ. Effective targeting of TAG72+ peritoneal ovarian tumors via regional delivery of CAR-engineered T cells. Front Immunol. 2018; 9 (2268).

77. Zheng DQ, Woodard AS, Fornaro M, Tallini G, Languino LR. Prostatic carcinoma cell migration via alpha(v)beta3 integrin is modulated by a focal adhesion kinase pathway. Cancer Res. 1999; 59 (7): 1655-1664.

78. Stucci S, Tucci M, Passarelli A, Silvestris F. Avbeta3 integrin: Pathogenetic role in osteotropic tumors. Crit Rev Oncol Hematol. 2015; 96 (1): 183-193.

79. McCabe NP, De S, Vasanji A, Brainard J, Byzova TV. Prostate cancer specific integrin alphavbeta3 modulates bone metastatic growth and tissue remodeling. Oncogene. 2007; 26 (42): 6238-6243.

80. McNeel DG, Eickhoff J, Lee FT, King DM, Alberti D, Thomas JP, Friedl A, Kolesar J, Marnocha R, Volkman J, Zhang J, Hammershaimb L, Zwiebel JA, Wilding G. Phase I trial of a monoclonal antibody specific for alphavbeta3 integrin (MEDI-522) in patients with advanced malignancies, including an assessment of effect on tumor perfusion. Clin Cancer Res. 2005; 11(21): 7851-7860.

81. Raab-Westphal S, Marshall JF, Goodman SL. Integrins as Therapeutic Targets: Successes and Cancers. Cancers. 2017; 9(9): 110.

82. Wallstabe L, Mades A, Frenz S, Einsele H, Rader C, Hudecek M. CAR T cells targeting alphavbeta3 integrin are effective against advanced cancer in preclinical models. Adv Cell Gene Ther. 2018; 1 (2): 10.

83. Blumenthal RD, Leon E, Hansen HJ, Goldenberg DM. Expression patterns of CEACAM5 and CEACAM6 in primary and metastatic cancers. BMC Cancer. 2007; 7(1): 2.

84. Parkhurst MR, Yang JC, Langan RC, Dudley ME, Nathan D-AN, Feldman SA, Davis JL, Morgan RA, Merino MJ, Sherry RM, Hughes MS, Kammula US, Phan GQ, Lim RM, Wank SA, Restifo NP, Robbins PF, Laurencot CM, Rosenberg SA. $\mathrm{T}$ cells targeting carcinoembryonic antigen can mediate regression of metastatic colorectal cancer but induce severe transient colitis. Mol Ther. 2011, 19(3): 620-626.

85. Thistlethwaite FC, Gilham DE, Guest RD, Rothwell DG, Pillai M, Burt DJ, Byatte AJ, Kirillova N, Valle JW, Sharma SK, Chester KA, Westwood NB, Halford SER, Nabarro S, Wan S, Austin E, Hawkins RE. The clinical efficacy of first-generation carcinoembryonic antigen (CEACAM5)-specific CAR
T cells is limited by poor persistence and transient pre-conditioning-dependent respiratory toxicity. Cancer Immunol Immunother. 2017; 66 (11): 1425-1436.

86. Katz SC, Burga RA, McCormack E, Wang LJ, Mooring W, Point GR, Khare PD, Thorn M, Ma Q, Stainken BF, Assanah EO, Davies R, Espat NJ, Junghans RP. Phase I hepatic immunotherapy for metastases study of intra-arterial chimeric antigen receptor-modified T-cell therapy for CEA+ liver metastases. Clin Cancer Res. 2015; 21(14): 3149-3159.

87. Zhang C, Wang Z, Yang Z, Wang M, Li S, Li Y, Zhang R, Xiong Z, Wei Z, Shen J, Luo Y, Zhang Q, Liu L, Qin H, Liu W, Wu F, Chen W, Pan F, Zhang X, Bie P, Liang H, Pecher G, Qian C. Phase I Escalating-dose trial of CAR-T therapy targeting $\mathrm{CEA}(+)$ metastatic colorectal cancers. Mol Ther. 2017; 25(5): 1248-1258.

88. Wong WY, Tanha J, Krishnan L, Tian B, Kumar P, Gaspar K, Demas S, Rohmann S, Chao H. Abstract A74: CAR-T cells harboring camelid single domain antibody as targeting agent to CEACAM6 antigen in pancreatic cancer. Cancer Immunol Res. 2017; 5 (3 Supplement): A74-A74.

89. Trerotola M, Rathore S, Goel HL, Li J, Alberti S, Piantelli M, Adams D, Jiang Z, Languino LR. CD133, Trop-2 and alpha2beta1 integrin surface receptors as markers of putative human prostate cancer stem cells. Am J Transl Res. 2010; 2(2): 135-144.

90. Trerotola M, Ganguly KK, Fazli L, Fedele C, Lu H, Dutta A, Liu Q, De Angelis T, Riddell LW, Riobo NA, Gleave ME, Zoubeidi A, Pestell RG, Altieri DC, Languino LR. Trop-2 is up-regulated in invasive prostate cancer and displaces FAK from focal contacts. Oncotarget. 2015; 6(16): 14318-14328.

91. Stein R, Chen S, Sharkey RM, Goldenberg DM. Murine monoclonal antibodies raised against human non-small cell carcinoma of the lung: specificity and tumor targeting. Cancer Res. 1990; 50(4): 1330-1336.

92. Bardia A, Mayer IA, Vahdat LT, Tolaney SM, Isakoff SJ, Diamond JR, O'Shaughnessy J, Moroose RL, Santin AD, Abramson VG, Shah NC, Rugo HS, Goldenberg DM, Sweidan AM, Iannone R, Washkowitz S, Sharkey RM, Wegener WA, Kalinsky K. Sacituzumab Govitecan-hziy in refractory metastatic triple-negative breast cancer. New Engl J Med. 2019; 380 (8): 741-751.

93. Zang X, Thompson RH, Al-Ahmadie HA, Serio AM, Reuter VE, Eastham JA, Scardino PT, Sharma P, Allison JP. $\mathrm{B} 7-\mathrm{H} 3$ and $\mathrm{B} 7 \mathrm{x}$ are highly expressed in human prostate cancer and associated with disease spread and poor outcome. Proc Nat Acad Sci USA. 2007; 104(49): 19458-19463.

94. Loo D, Alderson RF, Chen FZ, Huang L, Zhang W, Gorlatov S, Burke S, Ciccarone V, Li H, Yang Y, Son T, Chen Y, Easton AN, Li JC, Rillema JR, Licea M, Fieger C, Liang TW, Mather JP, Koenig S, Stewart SJ, Johnson S, Bonvini E, Moore PA. Development of an Fc-enhanced anti-B7-H3 monoclonal antibody with potent antitumor activity. Clin Cancer Res. 2012; 18 (14): 3834-3845.

95. Picarda E, Ohaegbulam KC, Zang X. Molecular pathways: targeting B7-H3 (CD276) for human cancer immunotherapy. Clin Cancer Res. 2016; 22(14): 3425-3431. 
96. Janakiram M, Shah UA, Liu W, Zhao A, Schoenberg MP, Zang X. The third group of the B7-CD28 immune checkpoint family: HHLA2, TMIGD2, B7x, and B7-H3. Immunol Rev. 2017; 276 (1): 26-39.

97. Lichtman E, Du H, Savoldo B, Ferrone S, Li G, Su L, Dotti G. Pre-clinical evaluation of B7-H3-specific chimeric antigen receptor T-cells for the treatment of acute myeloid leukemia. Blood. 2018;132 (Suppl 1): 701-701.

98. Zhao Q, Liu J, Yang S. Therapeutically targeting B7-H3 via chimeric antigen receptors and bispecific killer cell engagers in non-small cell lung cancer. J Immunol. 2018; 200 (1 Supplement): 179.113-179.113.

99. Soldano F, Dotti G. grantome.com/grant/NIH/R03CA223886-01.

100. Kurokawa T, Yamada T, Cai L, Ferrone S, Ferrone CR. B7-H3-specific chimeric-antigen receptor T-cell based immunotherapy for intrahepatic cholangiocarcinoma. J Am Coll Surg. 2018; 227 (4 Suppl 1): S236.

101. Majzner RG, Theruvath JL, Nellan A, Heitzeneder S, Cui Y, Mount CW, Rietberg SP, Linde MH, Xu P, Rota C, Sotillo E, Labanieh L, Lee DW, Orentas RJ, Dimitrov DS, Zhu Z, St. Croix B, Delaidelli A, Sekunova A, Bonvini E, Mitra SS, Quezado MM, Majeti R, Monje M, Sorensen PH, Maris JM, Mackall CL. CAR T cells targeting B7-H3, a pan-cancer antigen, demonstrate potent preclinical activity against pediatric solid tumors and brain tumors. Clin Cancer Res. 2019; 25(8): 2560-2574.

102. Graef CM, Mackall C, Theruvath J, Majzner R, Heitzeneder S, Mitra SS, Nellan A, Cui K, Cheshier SH. IMMU-45. Checkpoint molecule B7-H3 is highly expressed on medulloblastoma and proves to be a promising candidate for CAR T cell immunotherapy. Neuro-Oncology. 2017; 19 (Suppl_6): vi122-vi122.

103. Chow K, Heitzeneder S, Xu P, Theruvath J, Mitra S, Cheshier S, Li G, Mackall C. 327 B7-H3 chimeric antigen receptor modified $\mathrm{T}$ cells show potent anti-tumor activity in a preclinical model of glioblastoma. Neurosurgery. 2017; 64 (CN_suppl_1): 272-272.

104. Powderly J, Cote G, Flaherty K, Szmulewitz RZ, Ribas A, Weber J, Loo D, Baughman J, Chen F, Moore P, Bonvini E, Vasselli J, Wigginton J, Cohen R, Burris H, Chmielowski B. Interim results of an ongoing Phase I, dose escalation study of MGA271 (Fc-optimized humanized anti-B7-H3 monoclonal antibody) in patients with refractory B7-H3-expressing neoplasms or neoplasms whose vasculature expresses B7-H3. J Immunother Cancer. 2015; 3 (2): O8.

105. Steinberger P, Majdic O, Derdak SV, Pfistershammer K, Kirchberger S, Klauser C, Zlabinger G, Pickl WF, Stöckl J, Knapp W. Molecular characterization of human 4Ig-B7-H3, a member of the B7 family with four Ig-like domains. J Immunol. 2004; 172 (4): 2352-2359.

106. Smith JB, Lanitis E, Dangaj D, Buza E, Poussin M, Stashwick C, Scholler N, Powell DJ, Jr. Tumor regression and delayed onset toxicity following B7-H4 CAR T cell therapy. Mol Ther. 2016; 24 (11): 1987-1999.
107. Lee JK, Bangayan NJ, Chai T, Smith BA, Pariva TE, Yun S, Vashisht A, Zhang Q, Park JW, Corey E, Huang J, Graeber TG, Wohlschlegel J, Witte ON. Systemic surfaceome profiling identifies target antigens for immune-based therapy in subtypes of advanced prostate cancer. Proc Nat Acad Sci USA. 2018; 115 (19): E4473-E4482.

108. Wu X, Li J, Connolly EM, Liao X, Ouyang J, Giobbie-Hurder A, Lawrence D, McDermott D, Murphy G, Zhou J, Piesche M, Dranoff G, Rodig S, Shipp M, Hodi FS. Combined anti-VEGF and anti-CTLA-4 therapy elicits humoral immunity to galectin-1 which is associated with favorable clinical outcomes. Cancer Immunol. Res. 2017; 5 (6): 446454.

109. Jhaveri DT, Kim MS, Thompson ED, Huang L, Sharma R, Klein AP, Zheng L, Le DT, Laheru DA, Pandey A, Jaffee EM, Anders RA. Using quantitative seroproteomics to identify antibody biomarkers in pancreatic cancer. Cancer Immunol. Res. 2016; 4 (3): 225-233.

110. Briggs AW, Goldfless SJ, Timberlake S, Belmont BJ, Clouser CR, Koppstein D, Sok D, Heiden JVA, Tamminen MV, Kleinstein SH, Burton DR, Church GM, Vigneault F. Tumor-infiltrating immune repertoires captured by single-cell barcoding in emulsion. bioRxiv. 2017; DOI: 10.1101/134841. 


\title{
Метастатический рак простаты в эпоху CAR T-клеточной терапии: «Полцарства за мишень!»
}

\author{
Сергей В. Кулемзин ${ }^{1}$, Андрей А. Горчаков ${ }^{1,2}$, Александр В. Таранин ${ }^{1,2}$ \\ ${ }^{1}$ Институт молекулярной и клеточной биологии СО РАН, Новосибирск, Россия \\ ${ }^{2}$ Новосибирский государственный университет, Новосибирск, Россия
}

\section{Резюме}

Несмотря на значительный прогресс в области таргетной, химио- и радиотерапии, количество вариантов для пациентов с метастатическим кастрационно-резистентным раком предстательной железы остается невысоким. Большие надежды возлагались на дендритно-клеточные вакцины, в частности на sipuleucel-T, однако не все пациенты отвечают на этот тип терапии. Учитывая впечатляющий успех CAR T-клеток для лечения онкогематологических заболеваний, многие исследовательские группы начали разработку подходов CAR T-клеточной терапии кастрационно-резистентного рака предстательной железы. Из-за этого особенно актуальным стал вопрос об уникальных белках-мишенях рака простаты для CAR T-клеточной терапии. В идеале такие белки должны отсутствовать на поверхности нормальных клеток, экспрессироваться на всех раковых клетках у всех пациентов и быть незаменимыми для выживания раковой клетки. На практике, однако, ни один из описанных к настоящему моменту поверхностных белков-маркеров рака простаты не отвечает всем указанным требованиям. В настоящем обзоре рассмотрены основные белки-мишени для CAR T-клеточной терапии рака простаты, обсуждается их безопасность и потенциальная эффективность.

\section{Ключевые слова}

Метастатический рак предстательной железы, иммунотерапия, химерные антигенные рецепторы, CAR Т-клетки. 